\title{
MEKANISME KOLABORASI UNTUK PENINGKATAN KAPASITAS MASYARAKAT DALAM PROGRAM KEBUN BIBIT RAKYAT DI KABUPATEN POHUWATO
}

\author{
CollaborationMechanismin Community Capacity Building Through The Program of Kebun \\ Bibit Rakyat Program at Pohuwato Regency
}

\author{
Ivana Butolo ${ }^{1}$, Lukman M. Baga ${ }^{2}$, dan Irdika Mansur ${ }^{3}$ \\ 1 Staf Bappeda Provinsi Gorontalo. E-mail: nou.vana@yahoo.com \\ ${ }^{2}$ Staff Pengajar Departemen Agribisinis. Fakultas Ekonomi \& Manajemen. Institut Pertanian Bogor. \\ E-mail: Lukmanmb@yahoo.com \\ 3 Staff Pengajar Departemen Silvikultur. Fakultas Kehutanan. Institut Pertanian Bogor \\ E-mail: irdikam@gmail.com
}

\begin{abstract}
Kebun Bibit Rakyat (KBR) is one of government's efforts to empower the society in order to combat degraded land through reforestation. This research aimed: 1) to identify the role of stakeholder in capacity building of the community within KBR program at Pohuwato regency. 2) to evaluate the capacity level of the community within KBR program at Pohuwato regency, 3) to formulate the collaborative strategy to the succeed of KBR program at Pohuwato regency. The datas were collected through interview, observation and questioners. The datas then were analyzed by using stakeholder analysis, gap, and SWOT. The results showed that 1) the stakeholder involved in KBR program was mostly dominated by primary stakeholder, meanwhile secondary stakeholder was not involved in KBR program even though from the identification, secondary stakeholder was concerned and influential enough towards the community capacity building within KBR program; 2) the evaluation of community capacity showed that there was gap occurred even though it was relatively small, both at the policy level, organizations and individuals; 3) based on SWOT analysis, there were some strategies that could be formulated into the programs, and they were mapped into strategic architecture portrait. Within this condition, collaboration is very important because every stakeholder would give contribution to the community capacity building.
\end{abstract}

Key words: Collaboration, stakeholders, community capacity building, Kebun Bibit Rakyat (KBR) program.

\section{ABSTRAK}

Program Kebun Bibit Rakyat (KBR) merupakan salah satu upaya pemerintah untuk lebih memberdayakan masyarakat dalam upaya untuk mengurangi laju kerusakan hutan dan lahan kritis. Penelitian ini bertujuan untuk 1) Mengidentifikasi peran stakeholder untuk meningkatkan kapasitas masyarakat dalam program KBR di Kabupaten Pohuwato, 2) Mengevaluasi tingkat kapasitas masyarakat dalam program KBR di Kabupaten Pohuwato, 3) Merumuskan strategi kolaborasi untuk keberhasilan program KBR di Kabupaten Pohuwato. Pengambilan data dilakukan dengan wawancara, observasi dilapangan dan kuesioner, kemudian data dianalisis dengan menggunakan analisis stakeholder, gap, dan SWOT. Hasil penelitian menunjukkan bahwa 1) Stakeholder yang terlibat dalam program KBR lebih didominasi oleh stakeholder primer, sementara stakeholder sekunder tidak dilibatkan dalam proses KBR padahal dari hasil identifikasi berkepentingan mempunyai pengaruh terhadap peningkatan kapasitas masyarakat dalam program KBR; 2) Evaluasi kapasitas masyarakat menunjukkan adanya gap yang terjadi walaupun relatif kecil, baik pada tingkat kebijakan, organisasi maupun individual; 3) berdasarkan hasil analisis SWOT diperoleh beberapa strategi yang kemudian dirumuskan kedalam beberapa program dan selanjutnya dipetakan kedalam gambar arsitektur 
strategik. Dalam kondisi inilah maka kolaborasi menjadi penting karena setiap stakeholder dapat memberikan kontribusinya bagi upaya peningkatan kapasitas masyarakat.

Kata Kunci: Kolaborasi, stakeholder, peningkatan kapasitas masyarakat, Program Kebun Bibit Rakyat (KBR)

\section{PENDAHULUAN}

\section{Latar Belakang}

Hutan termasuk salah satu sumberdaya alam yang memerlukan pengelolaan secara arif dan bijak guna mendukung pembangunan berkelanjutan. Menurut penjelasan Undang-Undang nomor 41 tahun 1999 tentang Kehutanan, hutan sebagai modal pembangunan nasional memiliki manfaat yang nyata bagi kehidupan dan penghidupan bangsa Indonesia, baik manfaat ekologi, sosial budaya maupun ekonomi, secara seimbang dan dinamis. Untuk itu hutan harus diurus dan dikelola, dilindungi dan dimanfaatkan secara berkesinambungan bagi kesejahteraan masyarakat Indonesia, baik generasi sekarang maupun yang akan datang.

Ishak (2003) mengemukakan bagi Indonesia hutan merupakan sumber daya yang penting dalam upaya menjaga kelangsungan pembangunan nasional, karena disamping merupakan sumber kekayaan alam hutan juga merupakan salah satu basis pertahanan nasional. Untuk itu hutan di samping dimanfaatkan secara optimal juga harus dipikirkan sekaligus aspek pelestariannya agar hutan tidak habis atau kehilangan daya dukungnya terhadap proses pembangunan.

Pada praktiknya, pengelolaan hutan seringkali tidak memperhatikan kepentingan keberlanjutan tersebut, baik secara ekologis, sosial maupun ekonomis. Secara perlahan tetapi meyakinkan telah terjadi kerusakan hutan yang sangat parah di Indonesia, hal ini disebabkan karena aktivitas penebangan liar, penyelundupan kayu, kebakaran hutan dan konversi kawasan hutan menjadi areal penggunaan lainnya yang semakin merajalela tanpa mengindahkan hukum dan kaidah-kaidah pengelolaan hutan yang lestari.

Kabupaten Pohuwato merupakan salah satu wilayah dari Provinsi Gorontalo, kabupaten ini berada di ujung barat wilayah Provinsi Gorontalo dengan luas wilayah 4.244,31 $\mathrm{km}^{2}$. Keberadaan hutan yang luas di kabupaten ini terbentang dari Kecamatan Paguat sampai Kecamatan Popayato Barat dengan luas hutan 372.417 Ha atau terbesar di Provinsi Gorontalo. Namun saat ini kondisi hutan di Kabupaten Pohuwato telah mengalami banyak kerusakan akibat adanya aktivitas pengelolaan hutan, penebangan liar yang terjadi akibat fungsi-fungsi unit manajemen tidak optimal. Rehabilitasi Hutan dan Lahan (RHL) merupakan salah satu upaya untuk memulihkan kerusakan sumber daya hutan dan lahan yang semakin meluas tersebut.

Salah satu upaya pemerintah untuk lebih memberdayakan masyarakat dalam upaya untuk mengurangi laju kerusakan hutan dan lahan kritis adalah melalui kegiatan rehabilitasi hutan dan lahan yang berbasis pemberdayaan masyarakat yaitu program Kebun Bibit Rakyat (KBR). Program KBR ini merupakan fasilitasi pemerintah dalam penyediaan bibit tanaman hutan dan dan jenis tanaman serbaguna yang dibuat secara swakelola oleh masyarakat. KBR diharapkan dapat digunakan sebagai wahana pembelajaran bagi masyarakat dalam pembuatan pembibitan secara baik dan benar. Proses ini diarahkan agar setiap upaya pemberdayaan dapat meningkatkan kapasitas mayarakat guna merealisasikan tujuan yang diinginkan bersama. Dalam hal ini perlu adanya kesamaan sikap dan tindakan yang terkoordinasi oleh seluruh aktor dalam sektor kehutanan. Kerusakan hutan dan lahan merupakan masalah yang 
harus ditangani secara serius oleh kolaborasi seluruh pihak untuk memulihkan, mempertahankan dan meningkatkan fungsi hutan dan lahan sehingga daya dukung, produktivitas, dan peranannya dalam mendukung sistem penyangga kehidupan tetap terjaga.

\section{Perumusan Masalah}

1. Bagaimana peran stakeholder untuk meningkatkan kapasitas masyarakat dalam program KBR di Kab Pohuwato

2. Bagaimana tingkat kapasitas masyarakat dalam program KBR di Kab Pohuwato

3. Bagaimana strategi kolaborasi untuk keberhasilan program KBR di Kab Pohuwato.

\section{Tujuan Penelitian}

1. Mengidentifikasi peran stakeholder dalam meningkatkan kapasitas masyarakat dalam program KBR di Kab Pohuwato

2. Mengevaluasi tingkat kapasitas masyarakat dalam program KBR di Kab Pohuwato

3. Merumuskan strategi kolaborasi untuk keberhasilan program KBR di Kab Pohuwato

\section{METODE PENELITAN}

\section{Kerangka Pemikiran}

Kerusakan hutan dan lahan kritis telah menyebabkan mundurnya kualitas lingkungan yang antara lain ditandai dengan rendahnya produktivitas lahan, tingginya laju erosi dan besarnya peluang terjadinya banjir dan kekeringan yang akan mengakibatkan turunnya kualitas kehidupan. Untuk itu salah satu prioritas pembangunan sektor kehutanan sekarang ini sedang digalakkan untuk perbaikan permasalahan lingkungan seperti degradasi hutan dan lahan kritis.

Untuk memulihkan kembali fungsi hutan dan lahan kritis diperlukan upaya rehabilitasi hutan dan lahan sehingga daya dukung, produktifitas dan peranannya dalam mendukung sistem penyangga kehidupan tetap terjaga. Salah satu program pemerintah yaitu program Kebun Bibit Rakyat (KBR) yang diatur dalam Permenhut Nomor: P.12/MenHut-II/2013 tentang Pedoman Penyelenggaraan Kebun Bibit Rakyat, merupakan bentuk fasilitasi pemerintah dalam penyediaan bibit tanaman hutan dan jenis tanaman serbaguna yang prosesnya dibuat secara swakelola oleh kelompok tani. Tahapan kegiatan dalam program KBR yakni tahap perencanaan, pelaksanaan, dan pengawasan/pelaporan (Gambar 1).

\section{Lokasi dan Waktu Kajian}

Penelitian ini dilaksanakan pada bulan April-Mei 2014 di Kab Pohuwato, Provinsi Gorontaolo.

\section{Jenis dan Teknik Pengumpulan Data}

Jenis data yang digunakan dalam penelitian ini terdiri dari data primer dan data sekunder. Data primer merupakan data yang diperoleh langsung dilapangan, melalui proses observasi, kuesioner dan wawancara dengan informan yang telah ditentukan. Sedangkan data sekunder merupakan data yang diperoleh dari instansi terkait atau dokumen yang ada pada lembaga-lembaga oleh SKPD terkait, dukungan regulasi serta dokumen presentasi kebijakan daerah yang relevan dalam penelitian ini.

\section{Metode Pengambilan Sampel}

Teknik pengambilan sampel dalam penelitian ini secara purposive. Sampel yang dipilih dalam penelitian ini adalah kelompok masyarakat program KBR, institusi pemerintah, non pemerintah yang terkait kepentingan dengan program KBR di Kabupaten Pohuwato. 


\section{Analisis Data}

Tabel 1. Analisis Data

\begin{tabular}{|c|c|c|c|}
\hline No & Tujuan Penelitian & Metode Analisis & Hasil yang diharapkan \\
\hline 1. & $\begin{array}{l}\text { Mengidentifikasi } \\
\text { peran stakeholder } \\
\text { dalam pelaksanaan } \\
\text { program KBR }\end{array}$ & $\begin{array}{l}\text { Analisis Stakeholder } \\
\text { Mengidentifikasi kepentingan dan } \\
\text { pengaruh stakeholder baik yang } \\
\text { sudah terlibat atau yang belum. }\end{array}$ & $\begin{array}{l}\text { Mengkategorisasikan } \\
\text { stakeholder berdasarkan } \\
\text { pengaruh dan kepentingan } \\
\text { dalam sebuah sinergi kolaborasi }\end{array}$ \\
\hline 2. & $\begin{array}{l}\text { Mengevaluasi } \\
\text { kapasitas masyarakat } \\
\text { dalam program KBR }\end{array}$ & $\begin{array}{l}\text { Analisis GAP } \\
\text { Menilai seberapa besar } \\
\text { kesenjangan antara kinerja aktual } \\
\text { dengan sesuatu yang diharapkan }\end{array}$ & $\begin{array}{l}\text { Menggambarkan serta } \\
\text { menjelaskan secara } \\
\text { komprehensif tingkat kapasitas } \\
\text { masyarakat dalam program } \\
\text { KBR. }\end{array}$ \\
\hline 3. & $\begin{array}{l}\text { Merumuskan Strategi } \\
\text { kolaborasi untuk } \\
\text { keberhasilan program } \\
\text { KBR }\end{array}$ & $\begin{array}{l}\text { Analisis SWOT } \\
\text { Basis Utama: Kelompok } \\
\text { Masyarakat, Aspek Internal: } \\
\text { Sumberdaya Kelembagaan } \\
\text { formal, Aspek Eksternal: Faktor } \\
\text { Politik \& Faktor Jaringan Kerja }\end{array}$ & $\begin{array}{l}\text { Rumusan Strategi Kolaborasi } \\
\text { untuk keberhasilan program } \\
\text { KBR }\end{array}$ \\
\hline
\end{tabular}

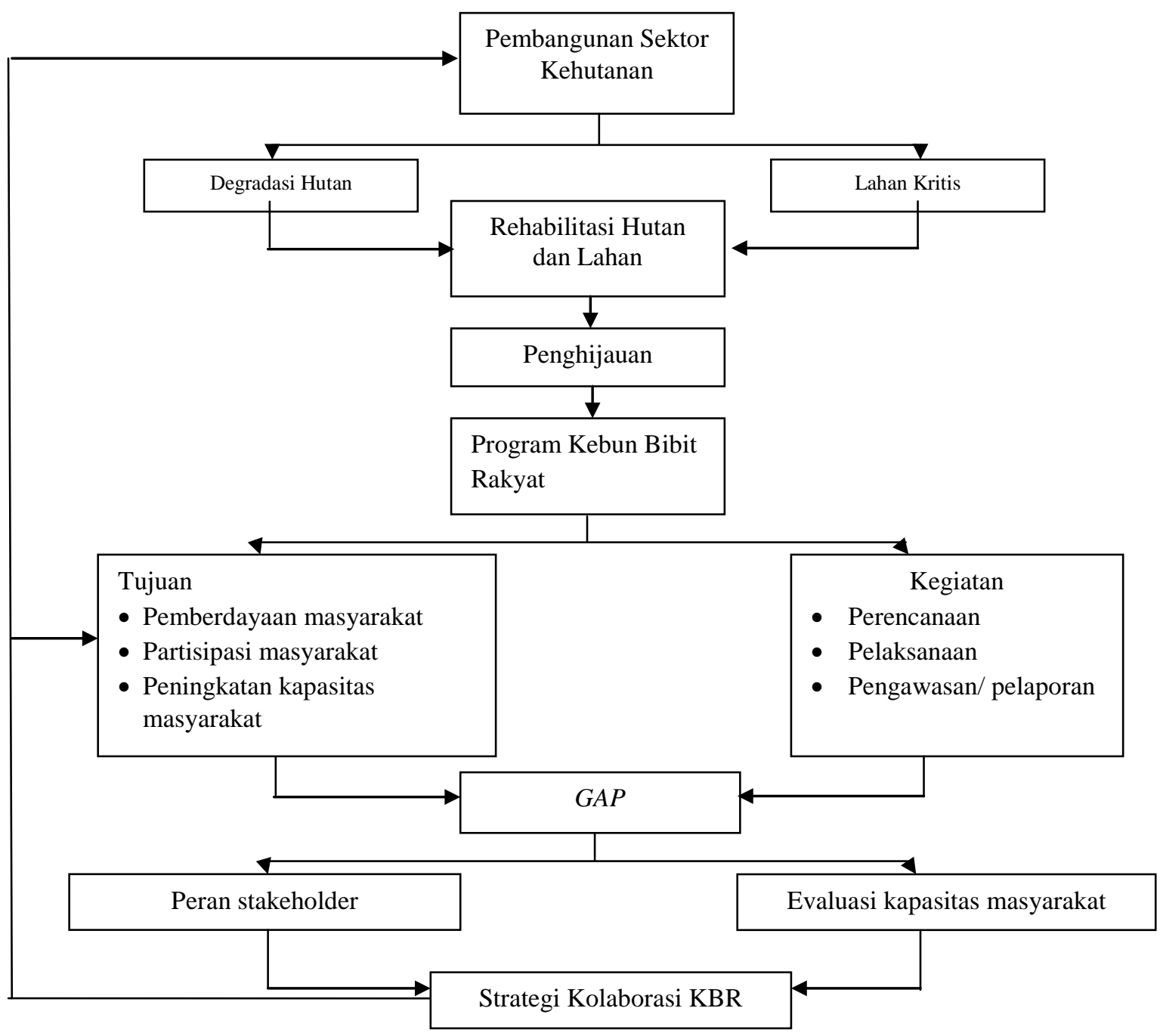

Gambar 1 Kerangka Pemikiran 


\section{HASIL DAN PEMBAHASAN}

\section{Identifikasi Peran Stakeholder Dalam Peningkatan Kapasitas Masyarakat}

Analisis ini dimulai dengan menyusun stakeholder berdasarkan keterlibatan maupun belum dalam program KBR yang berpengaruh terhadap upaya peningkatan kapasitas masyarakat. Hasil identifikasi peran stakeholder menunjukkan ada dua kategorisasi stakeholder, yang dapat dibedakan atas stakeholder primer yaitu stakeholder yang terlibat dan mempunyai kaitan kepentingan dan berpengaruh dalam kegiatan KBR yang terdiri dari 1) Bupati, 2) BPDAS Bone Bolango, 3) Dinas Kehutanan dan Pertambangan Kabupaten Pohuwato, 4) Kepala Desa, 5) Petugas lapangan, 6) Koordinator sumber benih dan stakeholder sekunder yaitu stakeholder yang tidak bertanggung jawab langsung dalam pelaksanaan program KBR namun sesuai identifikasi mempunyai kepentingan dan pengaruh terhadap program tersebut terdiri dari 1) BP4K Kabupaten Pohuwato , 2) BLH Kabupaten Pohuwato, 3) Bappeda Kabupaten Pohuwato, 4) DPRD Kabupaten Pohuwato, 5) LSM, 6) Perguruan Tinggi, 7) Camat, 8) Pemuka agama.

Keenam stakeholder primer ini belum mewakili semua sektor yang berpotensi untuk membangun kolaborasi sebagai upaya meningkatkan kapasitas masyarakat karena masih banyaknya stakeholder sekunder yang belum terlibat langsung padahal mempunyai pengaruh dan kepentingan dalam peningkatan kapasitas masyarakat. Seperti dalam penelitian Elvida dan Alviya (2009) yang mengemukakan bahwa permasalahan utama yang ditemui di lapangan terkait dengan pembangunan $\mathrm{KPH}$ antara lain adalah faktor sosial ekonomi dan kelembagaan yang meliputi belum bersinerginya antara stakeholder yang terkait dalam membangun $\mathrm{KPH}$ dan rancangan perencanaan yang belum optimal sehingga implementasi pembangunan KPH masih rendah. $\begin{array}{ccr}\text { Langkah } & \text { selanjutnya } & \text { adalah } \\ \text { mengklasifikasikan } & \text { stakeholder } & \text { pada }\end{array}$ matriks menurut penting dan pengaruhnya terhadap peningkatan kapasitas masyarakat. Menurut Suporahardjo (2005), pengukuran derajat pentingnya dinilai dari besarnya peran dalam mencapai hasil dan tujuan proyek. Pengaruh dinilai kekuatan yang dapat mereka keluarkan untuk proses dan hasil proyek.

Berdasarkan kategorisasi stakeholder yang teridentifikasi diatas, kepentingan dan pengaruh stakeholder dalam program KBR sebagai upaya untuk meningkatkan kapasitas masyarakat diuraikan sebagai berikut:

1. Bupati. Bupati sebagai kepala pemerintah daerah, memiliki kepentingan dan pengaruh dalam pengelolaan KBR karena menyangkut kebijakan wilayah administrasi dan pembangunan daerah.

2. BPDAS Bone Bolango Provinsi Gorontalo. BPDAS merupakan instansi pusat di daerah yang tupoksinya secara spesifik untuk menangani masalah pengelolaan DAS, khususnya masalah perencanaan dan monev. Pengaruhnya juga besar dalam hal pendanaan pada program KBR

3. Dinas Kehutanan dan Pertambangan Kabupaten Pohuwato, adalah pelaksana langsung di lapangan program-program yang terkait dengan pengelolaan DAS termasuk program KBR sehingga mempunyai kemampuan untuk memobilisasi sumberdaya dalam keberhasilan program KBR serta upaya peningkatan kapasitas masyarakat.

4. Kepala Desa. Sebagai pucuk pimpinan tertinggi sekaligus wakil pemerintah di Desa, kepala desa berkepentingan terhadap manfaat langsung dari program KBR untuk kemakmuran warga desanya serta mempunyai pengaruh dalam pembinaan terhadap anggota kelompok masyarakat KBR.

5. Petugas lapangan/tenaga pendamping. Petugas lapangan/tenaga pendamping 
KBR ditetapkan untuk melakukan bimbingan kepada kelompok masyarakat pada setiap tahap rangkaian kegiatan program KBR, dalam artian petugas lapangan berpengaruh terhadap perencanaan, pelaksanaan dan pengawasan dalam program KBR.

6. Koordinator sumber benih. Sebagai koordinator sumber benih yang ditunjuk oleh BPTH Sulawesi untuk wilayah Gorontalo maka koordinator mempunyai keterlibatan secara langsung dalam hal penyediaan benih yang akan digunakan oleh kelompok masyarakat untuk pelaksanaan kegiatan KBR.

7. BP4K Kabupaten Pohuwato. Badan Penyuluh mempunyai kaitan yang cukup erat dengan pengelolaan sumberdaya hutan karena sesuai dengan tupoksinya dalam melaksanakan pembinaan teknis terhadap pengembangan mekanisme dan tata cara penyuluhan kehutanan.

8. BLH Kabupaten Pohuwato. Badan lingkungan hidup berkepentingan terhadap masalah pencemaran lingkungan yang berkaitan dengan kebakaran hutan dan lahan kritis. Melalui pembinaan teknis bidang pemantauan, pencegahan serta pemulihan kualitas lingkungan dapat meminimalisir masalah pencemaran lingkungan yang disebabkan oleh kerusakan hutan dan lahan kritis.

9. Bappeda Kabupaten Pohuwato. Instansi ini berkepentingan menjaring program-program dari instansi teknis lainnya maupun aspirasi dari masyarakat untuk dikoordinasikan dan disahkan. Selain itu, pengaruhnya juga besar dalam hal pendanaan karena instansi ini berwenang menyusun rencana anggaran pendapatan dan belanja daerah.

10. DPRD Kabupaten Pohuwato. Tupoksi DPRD tidak secara langsung berkaitan dengan kehutanan akan tetapi dalam banyak hal DPRD berkepentingan melakukan kontrol dan suport terhadap pemerintah daerah, terkait kebijakan pengelolaan program KBR untuk rehabilitasi hutan dan lahan selain itu pengaruhnya juga besar dalam penyusunan PERDA terkait.

11. LSM. Sebagai lembaga swadaya masyarakat berkepentingan untuk menjaga kelestarian hutan, penguatan kelembagaan masyarakat, pemberdayaan masyarakat serta fasilitasi komunikasi antar pihak yang berkepentingan.

12. Perguruan Tinggi. Tri Dharma Perguruan Tinggi mewajibkan lembaga pendidikan tinggi sebagai centre of excellence dalam hal pendidikan, penelitian, dan pengabdian. Perguruan tinggi berkepentingan untuk melakukan penelitian dan memberikan saransaran dan arahan dalam bentuk tulisan ataupun laporan tentang pengembangan program KBR.

13. Camat. Tugas pemerintahan seorang camat salah satunya adalah koordinasi pemberdayaan masyarakat diwilayah kepemimpinannya. Dalam artian seorang camat haruslah berperan dalam setiap program pemberdayaan masyarakat dengan melakukan pembinaan ataupun pengawasan dalam program KBR.

14. Pemuka agama. Sebagai pemuka agama di desa baik imam mesjid ataupun dewan gereja berkepentingan terhadap eksistensi umat dalam hal sikap dan perilaku masyarakat desa yang mendukung kelestarian sumberdaya hutan melalui pembinaan keagamaan. Klasifikasi stakeholder menurut kepentingan dan pengaruh tersebut diatas kemudian dipetakan pada Gambar 2. 


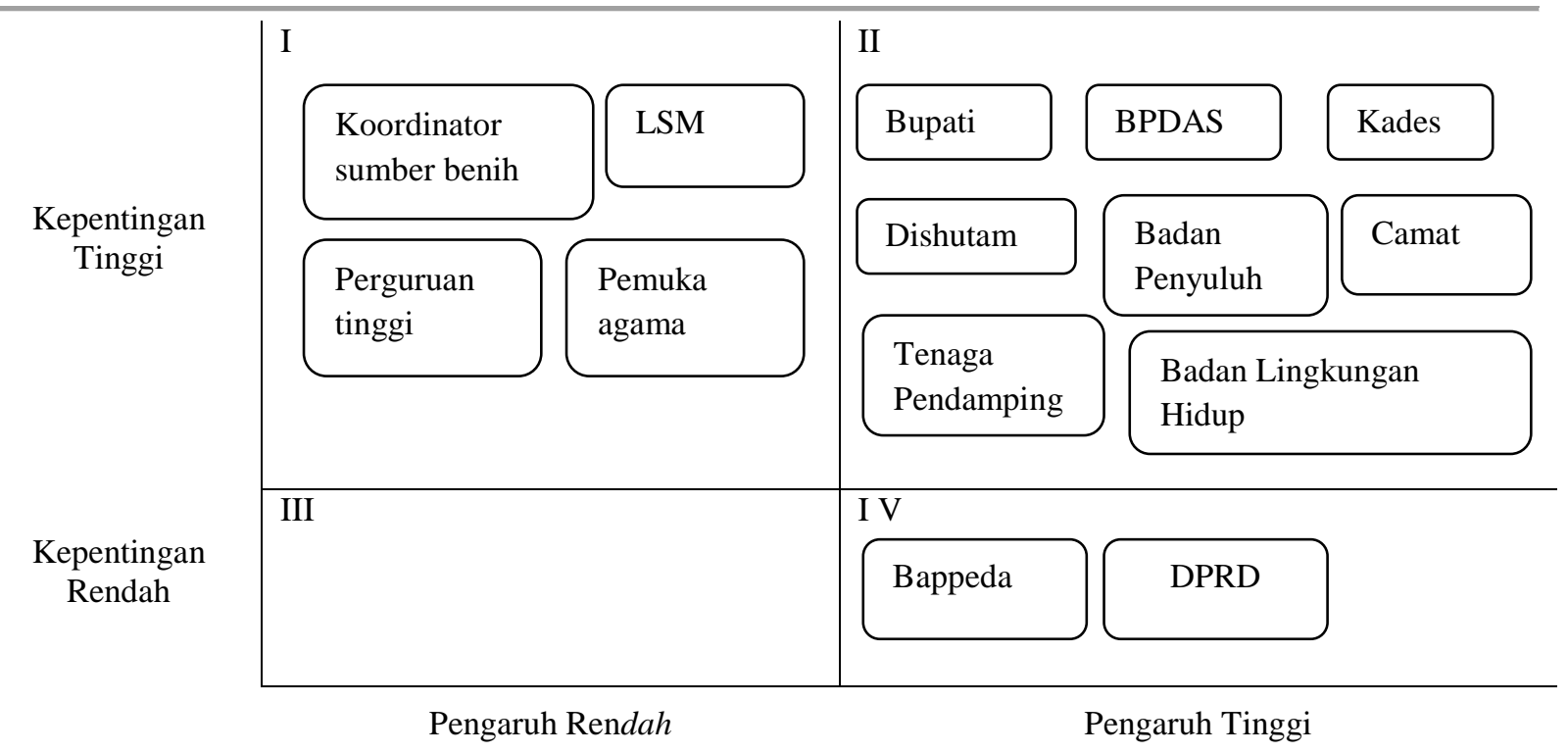

Gambar 2 Klasifikasi Stakeholder Pada Program KBR Di Kabupaten Pohuwato Menurut Kepentingan Dan Pengaruhnya Terhadap Peningkatan Kapasitas Masyarakat

Klasifikasi stakeholder berdasarkan kepentingan serta pengaruhnya dalam program KBR untuk meningkatkan kapasitas masyarakat (Gambar 2). Kuadran I adalah stakeholder yang mempunyai kepentingan tinggi namun memiliki pengaruh yang rendah. Stakeholder ini mempunyai minat yang besar terhadap KBR dengan ikut memberikan kontribusi bagi program KBR walaupun tidak mempunyai kekuasaan untuk mempengaruhi atau membuat peraturanperaturan tentang program KBR di Kabupaten Pohuwato.

Kuadran II adalah stakeholder dengan derajat pengaruh dan kepentingan tinggi terhadap keberhasilan program KBR. Stakeholder ini mempunyai pengaruh yang besar untuk melakukan sesuatu atau membuat aturan untuk pengelolaan program KBR guna meningkatkan kapasitas masyarakat. Selain itu peran yang dapat stakeholder lakukan juga besar sebagai upaya pencapaian hasil KBR.

Kuadran IV menunjukkan Stakeholder berpengaruh tinggi, tetapi derajat kepentingannya rendah. Penggolongan ini dilatarbelakangi oleh 60 lingkup kerja yang teramat luas, sedangkan masalah dalam bidang kehutanan telah ditangani oleh dinas teknis, sehingga dimasukkan dalam stakeholder dengan peran kecil tapi mempunyai pengaruh yang besar dalam mengesahkan programprogram dari dinas terkait yang berhubungan langsung dengan program KBR. Sementara itu pada kuadran III, tidak terdapat stakeholder yang mempunyai kepentingan rendah dan pengaruh rendah yang berpotensi sebagai ancaman semata bagi pengelolaan program KBR.

Pendekatan kolaborasi memberikan banyak manfaat sehingga pendekatan ini menjadi alternatif untuk membangun kerjasama antar stakeholder. Hal tersebut menekankan pada pentingnya bagaimana melakukan interaksi yang baik diantara para stakeholder dalam setiap kegiatan KBR. Seperti yang dikemukakan Winara, Aji dan Mukhtar, Abdullah (2011), bahwa optimalisasi kolaborasi harus intensif dilakukan untuk menyamakan pandangan tentang urgensi pengelolaan dan kontribusi nyata setiap pemangku kepentingan. Proses komunikasi dalam mengakomodasika berbagai kepentingan dan membangun konsensus bersama membutuhkan proses yang tidak cepat. Meskipun demikian, menurut Suparahardjo (2005), walaupun kolaborasi memiliki kesulitan dalam pelaksanaannya, meningkatnya kesuksesan dan manfaat kolaborasi dalam 
menyelesaikan permasalahan telah membuat pendekatan ini semakin populer. Kepedulian terhadap hutan harus disadarkan pada setiap individu masyarakat, namun tantangan terbesar adalah bagaimana memobilisasi kesadaran individu menjadi aksi kolektif dan kolaborasi stakeholder yang dapat menjadi gerbang awal kesinergian. Untuk mendukung kesinergian antar stakeholder dalam pelaksanaan program KBR dapat dilihat dari hubungan kolaborasi antar stakeholder (Tabel 2).

Tabel 2 Hubungan Kolaborasi Antar Stakeholder

\begin{tabular}{|c|c|c|}
\hline No & Kolaborasi Program & Stakeholder \\
\hline 1. & Tahap perencanaan & \\
\hline & - Sinkronisasi program terkait & $\begin{array}{l}\text { Bupati, DPRD, Bappeda, Dinas Kehutanan, } \\
\text { BPDAS, BP4K, BLH, kelompok masyarakat, } \\
\text { Perguruan Tinggi, LSM. }\end{array}$ \\
\hline & - Penyuluhan & $\begin{array}{l}\text { Dinas Kehutanan, BPDAS, BP4K, kelompok } \\
\text { masyarakat, Perguruan Tinggi, LSM }\end{array}$ \\
\hline & - Pembinaan & $\begin{array}{l}\text { Pemuka agama, kepala desa, camat, kelompok } \\
\text { masyarakat , LSM, Perguruan Tinggi }\end{array}$ \\
\hline 2. & Tahap pelaksanaan & $\begin{array}{l}\text { BPDAS, Dinas Kehutanan, BP4K, BLH, kelompok } \\
\text { masyarakat, tenaga pendamping, koordinator } \\
\text { sumber benih, LSM, Perguruan Tinggi }\end{array}$ \\
\hline 3. & Monitoring dan evaluasi & $\begin{array}{l}\text { Dinas Kehutanan, BPDAS, BP4K, BLH, kepala } \\
\text { desa, camat, LSM, Perguruan Tinggi, kelompok } \\
\text { masyarakat }\end{array}$ \\
\hline
\end{tabular}

Sumber: Data primer, 2014

Salah satu permasalahan yang terjadi dalam pelaksanaan program KBR di Kabupaten Pohuwato adalah kurangnya partisipasi antar stakeholder terkait. Upaya yang dapat dilakukan adalah mendorong partisipasi semua pihak dimulai dengan menginformasikan mengenai kegiatan KBR, melakukan koordinasi serta mensinkronkan kegiatan yang terkait antar stakeholder sehingga upaya peningkatan kapasitas melalui kolaborasi antar stakeholder dapat tercapai.

\section{Evaluasi Tingkat Kapasitas Masyarakat Dalam Program KBR}

Memenuhi tujuan penelitian ini, pengumpulan data dilakukan dengan menggunakan kuesioner. Agar hasil penelitian dapat dipertanggung jawabkan secara ilmiah, maka dilakukan uji validitas konstruk yaitu berdasarkan tingkatan pengembangan kapasitas. Dari pengolahan data dengan rumus korelasi product moment diperoleh hasil uji validitas yang kemudian secara statistik, angka korelasi dibandingkan dengan angka kritik Tabel korelasi nilai - r. Untuk taraf signifikasi 5\% angka kritik adalah 0,2638. Berhubung angka korelasi yang diperoleh di atas angka kritik 5\% maka dapat dikatakan bahwa item-item pernyataan tersebut dapat digunakan untuk mengukur dimensi yang diukur.

Langkah selanjutnya adalah menghitung kualitas kelompok masyarakat pada setiap tingkatan kebijakan, organisasi dan individu dengan menggunakan analisis gap. Muchsam (2011) mengemukakan secara umum analisis gap merupakan suatu metode atau alat yang digunakan untuk mengetahui tingkat kinerja dari sistem yang sedang berjalan dengan sistem standar, analisis ini merupakan salah satu langkah yang sangat penting dalam tahapan evaluasi kerja suatu program. Berdasarkan data kuesioner yang diperoleh dilapangan dan hasil perhitungan analisis gap menunjukkan bahwa selisih antara kinerja dan harapan semuanya bernilai negatif yang diuraikan sebagai berikut:

1. Tingkatan individual dengan gap sebesar 4,05. Rendahnya pengetahuan 
kelompok masyarakat dalam membuat bibit yang berkualitas disebabkan karena sebagian besar kelompok masyarakat KBR merupakan kelompok pemula yang baru berdiri. Sehingga pengetahuan dan kemampuan kelompok masyarakat dalam membuat, memelihara dan menanam bibit masih sangat rendah. Pada akhirnya kuantitas pencapaian bibit yang dihasilkan berada dibawah rencana yang ditetapkan pada awal penyusunan RUKK. Hal ini tentu saja membutuhkan kerjasama yang kuat antar stakeholder terkait melalui kolaborasi untuk memberikan pelatihan teknis ataupun penyuluhan kepada kelompok masyarakat KBR sehingga bisa meningkatkan kapasitas kelompok masyarakat tersebut.

2. Tingkatan organisasi dengan gap sebesar 3,25. Pemahaman yang tidak memadai dari kelompok masyarakat menyebabkan kesenjangan pada tingkatan organisasi. Akibatnya, organisasi kelompok yang seharusnya menjadi pengembangan wadah partisipasi, saling belajar antar kelompok masyarakat menjadi tidak optimal. Untuk itu, pengembangan organisasi ini perlu mendapat perhatian serius dari stakeholder terkait yang didasarkan pada praktekpraktek dan ilmu pengetahuan mengenai perilaku seperti kepemimpinan, dinamika kelompok, desain pekerjaan dengan partisipasi aktif sehingga akan meningkatkan efektifitas organisasi kelompok masyarakat KBR. Keefektifitasan organisasi kelompok masyarakat tentu saja dapat menambah pengetahuan dan kemampuan kelompok masyarakat tersebut.

3. Tingkatan kebijakan dengan gap sebesar 2,9. Kurangnya pelatihan, penyuluhan serta tenaga pendamping dalam program KBR mengakibatkan kesenjangan ini terjadi. Masalah dana yang hanya bersumber dari APBN melalui BPDAS dan tidak adanya dana pendamping dari APBD kabupaten sedikit menimbulkan permasalahan dalam kelancaran pelaksanaan program KBR. Untuk itu kedepannya perlu dipertimbangkan untuk segera mengajukan anggaran yang dapat mendukung kegiatan KBR yang bersumber dari dana APBD kabupaten.

Adanya gap yang terjadi pada tingakatan individual, organisasi dan tingkatan kebijakan perlu mendapatkan perhatian yang serius dari pemerintah daerah. Pemberlakuan kebijakan pengembangan kapasitas dengan memfasilitasi pembelajaran dan organisasi sehingga kelompok masyarakat dapat belajar meningkatkan pengetahuan, keterampilan dan mengubah perilaku sehingga dapat mencapai tujuan yaitu perbaikan kualitas hidup menjadi masyarakat yang mandiri.

\section{PERUMUSAN STRATEGI}

\section{Strategi Kolaborasi Dalam Program KBR}

Penyusunan strategi kolaborasi dalam program KBR adalah tahap penggabungan dengan teknik matriks SWOT. Analisis SWOT ini digunakan dengan menggabung antara faktor internal (kekuatan dan kelemahan) dengan faktor eksternal (peluang dan ancaman). Adapun hasil penggabungan keseluruhan strategi tersebut dapat dilihat pada Tabel 3.

\section{Strategi Strengths - Opportunities (S-O) \\ Strategi S-O merupakan} penggabungan faktor internal kekuatan dan faktor eksternal peluang dengan cara menggunakan kekuatan untuk memanfaatkan peluang. Strategi S-O dalam program KBR ini adalah:

a) Pemanfaatan kekuatan kelompok masyarakat untuk keberhasilan program KBR (S1, S2, S3, S4, S5, S6 - O1, O2, O3, O4, O5). Kekuatan 
masyarakat dapat lebih dioptimalkan dengan adanya berbagai peluang dari faktor eksternal. Apabila hal ini dapat dapat dikelola dengan baik maka akan memberikan manfaat yang besar terhadap lingkungan kawasan hutan, yaitu menurunkan emisi karbon (pro environment) serta untuk masyakat itu sendiri dalam hal peningkatan ekonomi masyarakat (pro growth) sekaligus penyerapan tenaga kerja (pro job) dan mengurangi kemiskinan (pro poor) yang menjadi latar belakang adanya program KBR.

\section{Strategi Strengths - Opportunities (S-O)}

Strategi S-O merupakan penggabungan faktor internal kekuatan dan faktor eksternal peluang dengan cara menggunakan kekuatan untuk memanfaatkan peluang. Strategi S-O dalam program KBR ini adalah:

a) Pemanfaatan kekuatan kelompok masyarakat untuk keberhasilan program KBR (S1, S2, S3, S4, S5, S6 - O1, O2, O3, O4, O5). Kekuatan masyarakat dapat lebih dioptimalkan dengan adanya berbagai peluang dari faktor eksternal. Apabila hal ini dapat dapat dikelola dengan baik maka akan memberikan manfaat yang besar terhadap lingkungan kawasan hutan, yaitu menurunkan emisi karbon (pro environment) serta untuk masyakat itu sendiri dalam hal peningkatan ekonomi masyarakat (pro growth) sekaligus penyerapan tenaga kerja (pro job) dan mengurangi kemiskinan (pro poor) yang menjadi latar belakang adanya program KBR.

b) Menciptakan iklim usaha yang kondusif untuk hasil panen KBR. (S1, S6 - O1, O2, O4). Strategi ini dilakukan agar pada saat panen dan menjual kayu hasil KBR dapat memberi rangsangan kepada dunia usaha sehingga harga kayu menjadi lebih baik. Dengan adanya jaminan Surat Keterangan Hasil Usaha
(SKHU) maka masyarakat akan semakin mengoptimalkan kinerjanya dalam program KBR.

c) Meningkatkan pengendalian keseimbangan persediaan bibit dan kebutuhan terhadap kayu (S1 - O4). Dengan adanya kekuatan yang dimiliki masyarakat serta adanya peluang dalam hal usulan penetapan areal Hutan Kemasyarakatan dan Hutan Desa maka masyarakat akan semakin terbiasa untuk menanam bibit karena pemanfaatan hasil hutan kayu akan semakin jelas. Dengan kondisi seperti ini maka akan ada keseimbangan anatara persediaan bibit dan kebutuhan terhadap kayu. 
Tabel 3. Matrik SWOT Strategi Kolaborasi Untuk Keberhasilan Program KBR Di Kabupaten Pohuwato

\begin{tabular}{|c|c|c|}
\hline Faktor Eksternal & $\begin{array}{l}\quad \text { Kekuatan (S) } \\
\text { 1. Lahan penanaman } \\
\text { 2. Kemampuan masyarakat } \\
\quad \text { dalam mengelola dana } \\
\text { 3. Kesiapan tenaga kerja } \\
\text { 4. Ketersediaan sumber air } \\
\text { 5. Tersedianya akses jalan di } \\
\quad \text { dalam kawasan hutan }\end{array}$ & $\begin{array}{l}\text { Kelemahan (W) } \\
\text { 1. Rendahnya tingkat pengetahuan } \\
\text { masyarakat } \\
\text { 2. Kurangnya pengalaman kerja } \\
\text { dalam bidang tanaman hutan } \\
\text { 3. Rendahnya kesadaran } \\
\text { masyarakat dalam menanam } \\
\text { bibit hasil KBR } \\
\text { 4. Kurangnya komitmen kelompok } \\
\text { masyarakat dalam pemeliharaan } \\
\text { bibit } \\
\text { 5. Keterlibatan kelompok } \\
\text { masyarakat hanya pada saat ada } \\
\text { program KBR }\end{array}$ \\
\hline $\begin{array}{l}\quad \text { Peluang (O) } \\
\text { 1. Peraturan Nomor P.12/ } \\
\text { Menhut-II/2013 } \\
\text { 2. Usulan penetapan areal kerja } \\
\text { HKm/HD oleh pemerintah } \\
\text { Kabupaten Pohuwato } \\
\text { 3. Komitmen yang tinggi dari } \\
\text { segenap aparat Dishut dalam } \\
\text { rehabilitasi hutan dan lahan } \\
\text { 4. Tingginya permintaan kayu } \\
\text { 5. Dukungan LSM dan } \\
\text { perguruan tinggi }\end{array}$ & \begin{tabular}{l}
\multicolumn{1}{c}{ Strategi S-O } \\
1. Pemanfaataan kekuatan \\
kelompok masyarakat, \\
untuk keberhasilan \\
program KBR \\
2. Menciptakan iklim usaha \\
yang kondusif untuk hasil \\
panen KBR \\
3. Meningkatkan \\
pengendalian \\
keseimbangan persediaan \\
bibit dan kebutuhan \\
terhadap kayu
\end{tabular} & $\begin{array}{l}\text { Strategi W-O } \\
\text { 1. Peningkatan kualitas SDM } \\
\text { kelompok masyarakat dalam } \\
\text { program KBR } \\
\text { 2. Melakukan pendampingan } \\
\text { untuk kelompok masyarakat }\end{array}$ \\
\hline $\begin{array}{l}\quad \text { Ancaman (T) } \\
\text { 1. Belum tersedianya dana } \\
\text { pendamping APBD } \\
\text { 2. Rendahnya koordinasi } \\
\text { Dishut antar stakeholder } \\
\text { lainnya } \\
\text { 3. Kurangnya jumlah tenaga } \\
\text { pendamping } \\
\text { 4. Belum adanya dukungan } \\
\text { PERDA tentang hutan rakyat } \\
\text { 5. Tidak efektifnya pelatihan } \\
\text { teknis } \\
\text { 6. Alih fungsi hutan dan lahan }\end{array}$ & \begin{tabular}{ll}
\multicolumn{1}{c}{ Strategi S-T } \\
1. & Pengajuan dana APBD \\
kepada Banggar \\
2. Peningkatan Komunikasi \\
dan koordinasi \\
stakeholder \\
3. Mendorong pemerintah \\
untuk terbitkan PERDA \\
Hutan Rakyat
\end{tabular} & $\begin{array}{l}\text { Strategi W-T } \\
\text { 1. Sosialisasi mengenai fungsi } \\
\text { hutan dan pemanfaatan hutan }\end{array}$ \\
\hline
\end{tabular}

Sumber: data primer, diolah, 2014.

\section{Strategi Weakness - Opportunities (W-O)}

Strategi W-O merupakan penggabungan faktor internal kelemahan dan faktor eksternal peluang dengan cara meminimalkan kelemahan untuk memanfaatkan peluang. Strategi W-O dalam program KBR ini adalah: a) Peningkatan kualitas SDM masyarakat dalam program KBR (W1, W2, W3, W4, W5 - O1, O2, O3, O4, O5). Sebelumnya program kehutanan lebih banyak dijalankan oleh pihak ketiga dimana masyarakat hanya terlibat pada saat penanaman saja. Dengan adanya program KBR yang menyerahkan 
semua pengelolaan langsung kepada masyarakat merupakan peluang yang besar bagi masyarakat untuk lebih ikut terlibat secara aktif dalam program kehutanan tersebut. Sehingga masyarakat ikut memiliki rasa bertanggung jawab terhadap pelestarian dan pengelolaan hutan. Hal ini tentu saja harus didukung oleh kapasitas yang memadai dari anggota kelompok masyarakat sehingga program KBR ini dapat tercapai dengan baik.

b) Melakukan pendampingan kepada kelompok masyarakat KBR (W1,W2, W3, W4, W5, - O1, O2, O3, O5). Rendahnya pengetahuan masyarakat mengenai cara pembuatan bibit yang baik dan benar menyebabkan banyak bibit yang mati dan tidak sesuai target yang tercantum dalm RUKK, hal ini membutuhkan kerjasama dari stakeholder terkait dalam bentuk pendampingan seperti penyuluhan, pelatihan kepada kelompok masyarakat. Selain itu rendahnya kesadaran masyarakat maupun kurangnya komitmen dan keterlibatan yang hanya karena ada program KBR memerlukan upaya fasilitasi bagi penyadaran perilaku individu untuk mencapai tujuan KBR itu sendiri. Pendampingan dapat berupa kemandirian, pengandalan diri, apresiasi terhadap pengetahuan dan kearifan lokal dan nilai-nilai baru yang diperlukan untuk kemajuan bersama.

\section{Strategi Strength - Tread (S-T)}

Strategi S-T merupakan penggabungan faktor internal kekuatan dan faktor eksternal ancaman dengan cara menciptakan strategi yang menggunakan kekuatan untuk mengatasi ancaman. Strategi S-T dalam program KBR ini adalah:

a) Pengajuan dana APBD kepada Badan Anggaran yang dapat mendukung program KBR (S1, S2, S3, S4, S5, S6
- T1, T3, T5). Anggaran yang dipergunakan dalam pelaksanaan program KBR keseluruhannya bersumber dari dana APBN. Hal ini menimbulkan permasalahan dalam tahapan awal pelaksanaan program karena kegiatan sosialisasi dan bimbingan teknis yang hanya menghadirkan masing-masing ketua kelompok dalam kegiatan tersebut serta minimnya jumlah tenaga pendamping lapangan. Oleh karena itu, kedepannya perlu dipertimbangkan untuk segera mengajukan permohonan anggaran pendukung dari APBD Kabupaten sehingga dapat menunjang pelaksanaan program KBR di Kabupaten Pohuwato.

b) Peningkatan komunikasi dan koordinasi stakeholder (S1, S3, S6 T2, T4, T6). Belum adanya wujud riil PERDA Hutan Rakyat menjadi salah satu masalah mendasar yang berakibat belum tercapainya tujuan pengelolaan hutan lestari. Perlu adanya komitmen dari semua pihak mengingat kepastian usaha dalam jangka panjang tidak dapat dicapai hanya melalui satu program atau proyek tertentu, melainkan diperlukan segenap program yang saling bersinergi. Selain itu perlu adanya perbaikan proses dan media penyebarluasan informasi mengenai KBR melalui rapat kerja, sehingga interaktif antar stakeholder dapat tercipta dengan baik.

c) Penyusunan PERDA Hutan Rakyat (W4, O1, O2, O3, O4, O5). Sistem pengelolaan hutan rakyat yang teratur belum dilakukan oleh masyarakat karena belum adanya PERDA yang mengatur hal tersebut. Akibatnya kelestarian dan kesinambungan hutan rakyat menjadi kekhawatiran dari beberapa pihak karena laju penebangan pohon relatif lebih cepat daripada laju penanamannya kembali. Oleh karena itu dalam rangka 
pengembangan hutan rakyat yang mendukung program KBR ini agar lebih terarah dan terpadu perlu segera di wujudkannya PERDA tentang hutan rakyat.

\section{Strategi Weakness - Tread (W-T)}

Strategi WT merupakan penggabungan faktor internal kelemahan dan faktor eksternal ancaman dengan cara meminimalkan kelemahan dan menghindari ancaman. Strategi W-T dalam program KBR ini adalah:

a) Sosialisasi mengenai fungsi hutan dan pemanfaatan hutan. Strategi ini dilatarbelakangi oleh kondisi kelemahan masyarakat, dengan adanya pemahaman melalui sosialisasi mengenai fungsi hutan maka masyarakat dapat bertahan untuk tidak melakukan hal-hal yang akan semakin memperburuk kondisi hutan disekitarnya dengan berbagai ancaman yang ada.

\section{Perumusan Program}

Strategi yang telah dirumuskan berdasarkan analisis SWOT selanjutnya dipetakan kedalam bentuk road map strategy, dengan tetap menganggap penting kesemua strategi yang telah dirumuskan pada tahapan sebelumnya. Beberapa program yang dapat diusulkan untuk mendukung keberhasilan program KBR melalui kolaborasi stakeholder guna meningkatkan kapasitas masyarakat di Kabupaten Pohuwato adalah sebagai berikut:

1. Program peningkatan kapasitas pengelolaan sumberdaya alam dan lingkungan. Program ini muncul dari hasil identifikasi penulis karena kelompok-kelompok masyarakat yang terbentuk lebih dilatarbelakangi oleh keinginan untuk mendapatkan bantuan dana. Akibatnya setelah program selesai, tidak ada rasa memiliki akan hasil yang diperoleh dari program KBR dan secara perlahan partisipasi masyarakat menurun dan tidak terlihat lagi. Beberapa kegiatan yang harus dilakukan untuk menunjang program tersebut adalah sebagai berikut:
a. Sosialisasi dampak dan pencegahan kerusakan hutan dan lahan
b. Pelatihan teknis
c. Penyuluhan
d. Fasilitasi pembinaan dan pendampingan masyarakat

2. Program optimalisasi program KBR. Pelaksanaan program KBR harus didukung oleh anggaran pendamping yang berasal dari dana APBD kabupaten. Masalah yang terjadi sekarang adalah, pelaksanaan sosialisasi KBR, Pelatihan pembuatan bibit hanya mengikutsertakan 1 orang wakil dari setiap kelompok masyarakat. Akibatnya anggota kelompok masyarakat lainnya tidak terlalu mengerti akan tujuan dan manfaat dari program KBR itu sendiri. Kegiatan-kegiatan yang dapat dilakukan dalam program ini diantaranya adalah:

a. Koordinasi perencanaan kegiatan

b. Forum sinkronisasi program dan kegiatan antar stakeholder

c. Peningkatan sarana dan prasarana

d. Konsultasi publik rancangan Perda Hutan Rakyat

e. Pembuatan regulasi alih fungsi hutan dan lahan

3. Program rehabilitasi dan perlindungan hutan. Kerusakan hutan dan lahan kritis dapat dicarikan solusinya melalui program rehabilitasi dan perlindungan hutan. Adanya bibit-bibit yang dihasilkan dalam program KBR sangat menunjang pelaksanaan program ini. Selain itu upaya kolaborasi dari pemerintah daerah adalah dengan memberikan bantuan bibit yang berasal dari dana APBD untuk masyarakat-masyarakat yang tidak mendapatkan bantuan dari program 
KBR, maka kegiatan penghijauan akan cepat direalisasikan. Beberapa kegiatan yang dilakukan dalam program ini antara lain yaitu:

a. Pemberdayaan masyarakat dalam gerakan rehabilitasi hutan dan lahan

b. Pengamanan hutan

4. Program pemantapan pemanfaatan hutan. Dengan kondisi masyarakat yang berdaya serta didukung oleh kebijakan dari pemerintah daerah maka, kondisi masyarakat akan menjadi lebih mandiri dalam hal memanfaatkan hutan sesuai dengan fungsinya. Kegiatan yang dapat dilakukan yaitu:
a. Pengembangan
Hutan
Kemasyarakatan/Hutan Desa
b. Peningkatan usaha masyarakat sekitar hutan
c. Monitoring dan evaluasi

Secara ringkas, tahapan dari pelaksanaan program tersebut diatas dapat digambarkan pada sebuah alur melalui pendekatan arsitektur strategik seperti pada Gambar 3.

\section{SIMPULAN DAN SARAN}

\section{Simpulan}

Dari hasil penelitian dan pembahasan yang disampaikan, maka disimpulkan beberapa hal sebagai berikut:

1. Stakeholder yang terlibat dalam program KBR lebih didominasi oleh stakeholder primer, sementara stakeholder sekunder tidak dilibatkan dalam proses program KBR padahal dari hasil identifikasi ada beberapa stakeholder sekunder yang berkepentingan dan mempunyai pengaruh terhadap peningkatan kapasitas masyarakat dalam program KBR. Upaya membangun kolaborasi antar stakeholder dapat dilakukan dalam program kerja yang saling bersinergi untuk mendukung pelaksanaan program
KBR, sehingga akan tercipta sebuah organisasi yang proaktif dan mempunyai kepekaan yang tinggi dalam upaya meningkatkan kapasitas masyarakat dalam pengelolaan program KBR dan kelestarian hutan.

2. Evaluasi kapasitas masyarakat pada program KBR dengan menggunakan analisis gap menunjukkan bahwa selisih antara kinerja dan harapan semuanya bernilai negatif baik pada tingkat kebijakan, organisasi maupun individual. Meskipun jumlah gap yang terjadi relatif kecil, akan tetapi tetap membutuhkan upaya kolaborasi dari semua stakeholder yang berkepentingan dan berpengaruh terhadap implementasi program KBR. Mulai dari tingkat kebijakan dengan membuat perumusan atau formulasi kebijakan yang memastikan pokok isu dari permasalahan yang dihadapi kelompok masyarakat. Pada tingkatan organisasi dengan lebih memperhatikan struktur dan proses yang dapat mendukung perubahan secara keseluruhan. Pada tingkat individual dengan lebih melakukan pendampingan kepada kelompok masyarakat serta bimbingan teknis tentang cara pembuatan bibit yang baik dan benar hingga proses pemeliharaan dan penanaman bibit KBR.

3. Strategi kolaborasi dalam program KBR berdasarkan hasil analisis SWOT kemudian dibuat dalam bentuk road map strategi dan merumuskan beberapa program yang kemudian dipetakan kedalam gambar arsitektur strategik. Dalam kondisi inilah maka kolaborasi stakeholder saling bersinergi sesuai dengan kontribusinya bagi upaya peningkatan kapasitas kelompok masyarakat pelaksana program KBR ataupun calon kelompok masyarakat penerima program KBR tahun mendatang di Kabupaten Pohuwato 


\section{Saran}

Apabila uraian hasil penelitian ini dapat disikapi positif oleh para pengambil kebijakan, maka beberapa hal yang penulis sarankan, yaitu :

1. Dalam implementasi program KBR yang berbasis pemberdayaan masyarakat perlu adanya pihak/lembaga non pemerintah yang menguasai teknik/teknik fasilitasi masyarakat dengan harapan setelah kegiatan KBR ini selesai dilaksanakan masyarakat dapat menjadi inisiator secara mandiri.

2. Perlu adanya upaya membangun kesepahaman dari semua stakeholder serta mensinkronkan kegiatan terkait antar stakeholder dengan membentuk forum kolaborasi pengelolaan KBR guna menciptakan hutan yang lestari.

3. Perlu adanya penambahan-penambahan kegiatan dan porsi pembelajaran yang lebih banyak untuk kelompok masyarakat. Untuk itu peran dan keberadaan fasilitator pendamping harus tetap diperhatikan sampai masyarakat benar-benar telah terbiasa dan mempunyai tingkat kemandirian serta berkapasitas tinggi dalam menjalankan prosespembangunan daerah.

\section{DAFTAR PUSTAKA}

Elvida, Alviya. 2009. Kendala dan Strategi Implementasi Pembangunan $\mathrm{KPH}$ Rinjani Barat. Pusat Penelitian Sosial Ekonomi dan Kebijakan Kehutanan, Bogor.

Ishak AF. 2003. Paradigma Hutan Lestari dan Pemberdayaan Masyarakat Lokal. Indomedia. Jakarta.

Muchsam Y. 2011. Penerapan Gap Analysis Pada Pengembangan Sistem Pendukung Keputusan Penilaian Kinerja Karyawan, Seminar Nasional Aplikasi Teknologi Informasi, ISSN 1907-5022, Yogyakarta.

Singarimbun M, Effendi S. 1987. Metode Penelitian Survai. LP3ES. Yogyakarta.

Suporahardjo, 2005, Manajemen Kolaborasi. Memahami Pluralisme Membangun Konsensus, Pustaka Latin, Bogor.

Winara A, Mukhtar AS. 2011. Potensi Kolaborasi Dalam Pengelolaan Taman Nasional Teluk Cendrawasih Di Papua. Jurnal Penelitian Hutan dan Konservasi Alam, Vol 8 No.3 217226. 


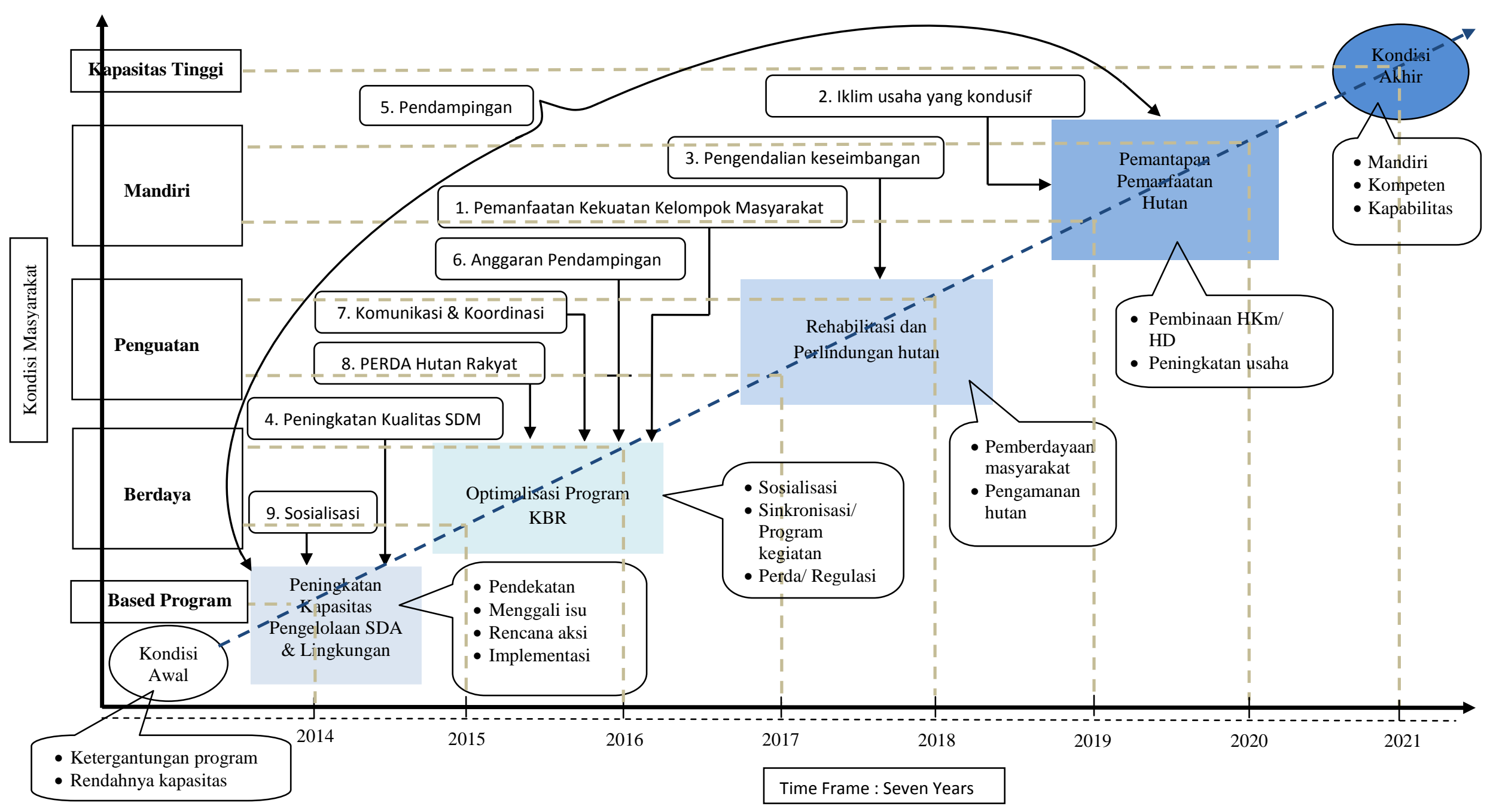

Gambar 3 Arsitektur strategik mekanisme kolaborasi dalam peningkatan kapasitas masyarakat 